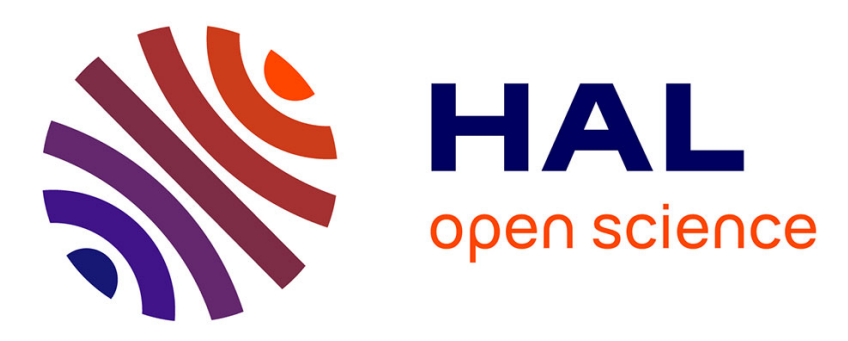

\title{
Reference solutions and URANS model characterization for turbulent forced convection around heated square cylinders
}

Xavier Nicolas, Hua Sun, Yannick Sommerer

\section{- To cite this version:}

Xavier Nicolas, Hua Sun, Yannick Sommerer. Reference solutions and URANS model characterization for turbulent forced convection around heated square cylinders. M. Deville et al. (eds). Turbulence and Interactions. TI2018, 149, Springer, pp.66-79, 2021, Notes in Numerical Fluid Mechanics and Multidiscipliary Design. hal-02641908

\section{HAL Id: hal-02641908 \\ https://hal.science/hal-02641908}

Submitted on 28 May 2020

HAL is a multi-disciplinary open access archive for the deposit and dissemination of scientific research documents, whether they are published or not. The documents may come from teaching and research institutions in France or abroad, or from public or private research centers.
L'archive ouverte pluridisciplinaire HAL, est destinée au dépôt et à la diffusion de documents scientifiques de niveau recherche, publiés ou non, émanant des établissements d'enseignement et de recherche français ou étrangers, des laboratoires publics ou privés. 


\title{
Reference solutions and URANS model characterization for turbulent forced convection around heated square cylinders
}

\author{
Xavier NICOLAS ${ }^{1[0000-0001-7161-6169]}$, Hua SUN $^{1}$ and Yannick SOMMERER ${ }^{2}$ \\ ${ }^{1}$ Université Paris Est Marne la Vallée, MSME UMR 8208 CNRS, 5 Bd Descartes, \\ 77454 Marne la Vallée Cedex 2, France. \\ 2 Airbus, 316 Route de Bayonne, 31060 Toulouse Cedex 09, France. \\ Xavier.Nicolas@u-pem.fr
}

\begin{abstract}
Reference solutions for the turbulent forced convection of air around heated square cylinders at high Reynolds numbers $\left(\mathrm{Re} \geq 10^{4}\right)$ are set-up from a bibliographical synthesis of about twenty experiments. These reference solutions concern the flow dynamics and heat transfer. We particularly focus on the local Nusselt number around the obstacle. These solutions are used to identify the URANS models that are the most adequate to reproduce the flow physics and heat transfer in this configuration. Different versions of the k- $\varepsilon$ and $k-\omega$ models are tested. It is shown that the k- $\omega$ SST model is the most accurate to evaluate the flow dynamics and the heat transfer: its accuracy is equivalent to that obtained by 3D LES and high performance computing.
\end{abstract}

Keywords: Heated square cylinder, Turbulent forced convection, Bibliographical review, Experimental reference solution, URANS simulations.

\section{Introduction}

In many industrial applications, an accurate prediction of the local convective heat transfer in the turbulent forced convection around heated bluff bodies is crucial. For instance, in the nacelle compartment of aeronautical engines, the equipment like valves, electrical harnesses, pumps or ducts is submitted to large heat fluxes in such a way that it must often be air-cooled to never exceed a maximum allowable temperature [1]. To optimize the cooling systems, accurate enough numerical simulations must be carried out. If correctly optimized and validated, URANS (Unsteady Reynolds Averaged Navier-Stokes) simulations can be preferred to LES to model a long period of a transient flow such as a complete flight mission for example. The objective of this communication is to define if an accurate prediction of the flow dynamics and heat transfer around heated bluff bodies is possible from URANS simulations and to test and characterize different $\mathrm{k}-\varepsilon$ and $\mathrm{k}-\omega$ models $[2,3]$.

In that aim, a 2D test case representative of the main physics and features encountered in this context is chosen. It is the ERCOFTAC benchmark proposed by Lyn, Rodi et al. [4-6] of an air flow around a square cylinder, placed transversally at midheight of a channel, at Reynolds number $\mathrm{Re}=22,000$, but considering that the cylinder 
is heated. A large experimental and numerical database of the flow dynamics for this test case or for similar configurations is available in the literature. There is also a thermal database thanks to the experiments around heated square cylinders [7-10]. Thus, to characterize the different URANS models used in the present paper and enable comparisons between experiments and simulations, reference solutions for the global characteristics of the flow dynamics and heat transfer have been first set-up from a bibliographical review of about twenty experiments.

The outline of the paper is the following. The flow dynamics is presented in $\S 2$, the synthesis of the bibliographical review in $\$ 3$ and the used URANS models, flow configuration and numerical methods in $\S 4$. The URANS results are then compared with the experimental reference results and discussed. The global quantities and statistics describing the flow dynamics and heat transfer are analyzed in $\S 5$, for four variants of the $k-\varepsilon$ and k- $\omega$ models. The local profiles around the square cylinder, computed with the k- $\omega$ SST model, are analyzed in $§ 6$. Conclusions are given in $§ 7$.

\section{Flow dynamics of the selected test case}

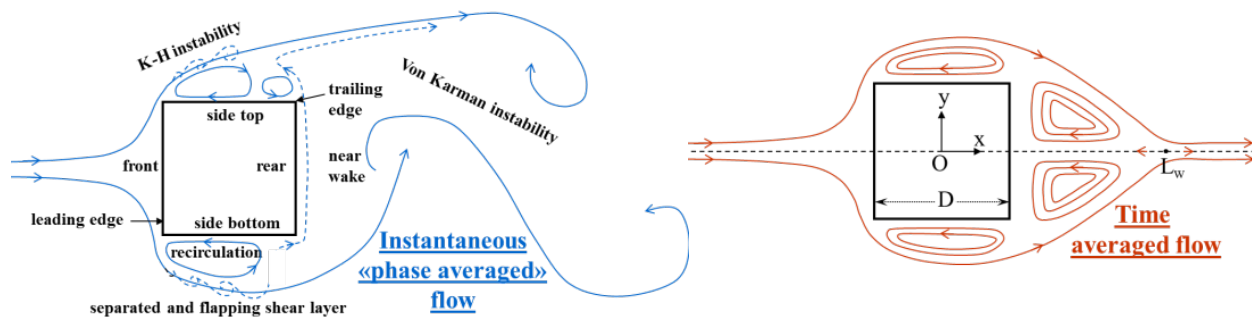

Fig. 1. Schematic representation of the instantaneous phase averaged and time averaged flow around a square cylinder at high Reynolds number.

Fig. 1 sums up in a simplified way the main patterns observed in the turbulent air flow around a square obstacle at $\operatorname{Re}=\mathrm{U}_{\infty} \mathrm{D} / \mathrm{v} \geq 10^{4}$, with $\mathrm{D}$ the length of the obstacle edge and $U_{\infty}$ the free stream velocity. In Fig. 1 (left), the blue lines more or less correspond to the stream lines of the instantaneous phase averaged flow. Two shear layers symmetrically separate from the top and bottom leading edges. A Kelvin-Helmholtz $(\mathrm{KH})$ instability intermittently develops in these shear layers [11-13] with, between them and the top and bottom faces of the square cylinder, two recirculations, very unstable over time, with a reverse flow near the wall. The shear layers do not reattach on the side walls, but eventually on the rear face. They flaps above and behind the trailing edges and they roll up as the Karman instability develops. The vortical structures associated with this instability are continuously and quasi periodically generated in the wake, while the $\mathrm{KH}$ vortical structures appear intermittently in the shear layers $[12,13]$. The frequencies associated with the two instabilities are clearly separated in the Fourier spectra of the velocity or pressure time signals: the Strouhal number $\mathrm{St}=\mathrm{fD} / \mathrm{U}_{\infty}$ of the Karman vortex shedding is approximately equal to 0.13 while it varies between 1 and 10 for the $\mathrm{KH}$ instability. In the near wake behind the obstacle, the 
turbulent intensity is very high and the instantaneous flow is complicated to describe. On the other hand, the time averaged flow is simple (Fig. 1 (right)): it is steady and symmetrical through the horizontal axis; the two separated shear layers are still present with two recirculations between them and the side walls; lastly, in the near wake, there are two steady contrarotative vortices with a reverse flow on the horizontal axis.

\section{Bibliographical review for reference solution setting-up}

Several quantities are quasi systematically measured to characterize the global dynamics of the just described flow. Their average values, with their dispersion margins, are compiled in Table 1 . They result from a synthesis of 17 experiments ([4-6, 11, 12, 14-20] among others), not detailed in the present paper. The first reported quantity is the dimensionless wake length, $L_{w} / D$, where $L_{w}$ is the length from the square center to the point where the averaged horizontal velocity, $\overline{\mathrm{u}}$, vanishes (cf. Fig. 1 (right)). $\mathrm{St}=\mathrm{fD} / \mathrm{U}_{\infty}$ is the Strouhal number with $\mathrm{f}$ the frequency of the vortex shedding. $\overline{\mathrm{C}_{\mathrm{d}}}, \mathrm{C}_{\mathrm{d}}$, and $\mathrm{C}_{l}$ ' are the time averaged drag coefficient, the RMS of the drag coefficient and the RMS of the lift coefficient respectively. $\overline{\mathrm{C}_{\mathrm{p}, \mathrm{b}}}=2\left(\overline{\mathrm{p}}-\mathrm{p}_{\infty}\right) / \rho_{\infty} \mathrm{U}_{\infty}^{2}$ is the time averaged base pressure coefficient, where $\bar{p}$ is the time averaged pressure on the rear face of the square cylinder ; $\mathrm{p}_{\infty}$ and $\rho_{\infty}$ are the free stream pressure and density respectively.

It is well known that these quantities and the flow structure do not depend on Re for $10^{4}$ to $2 \times 10^{4}<\operatorname{Re} \leq 5 \times 10^{6}$ [21]. On the other hand, they may depend on the inlet turbulence intensity, I, and the blockage effect, $\mathrm{D} / \mathrm{H}$, due to the presence of the cylinder in a finite size channel. When I increases, the inside and outside of the separated shear layers are more linked (the shear layers thicken); therefore the fluctuations of the lift force $\left(\mathrm{C}_{\mathrm{l}}\right)$ decrease, the base pressure $\left(\overline{\mathrm{C}_{\mathrm{p}, \mathrm{b}}}\right)$ increases and the drag force $\left(\overline{\mathrm{C}_{\mathrm{d}}}\right)$ decreases $[14,16,19]$. Note however that $C_{d}$ ' and $S t$ are very few influenced by $I$.

Table 1. Global characteristics of the flow around a square cylinder at $\mathrm{Re}>10^{4}$ resulting from the synthesis [21] and the present one. $\{$ BEC $\}$ blockage effect corrected values.

\begin{tabular}{|c|c|c|c|c|c|c|c|c|c|c|}
\hline Reference & Methods & $\begin{array}{c}\mathrm{Re} \\
\times 10^{-3} \\
\end{array}$ & I (\%) & $\mathrm{L}_{w} / \mathrm{D}$ & $\mathrm{S}_{\mathrm{t}}$ & $\overline{\mathrm{C}}_{\mathrm{d}}$ & $\mathrm{C}_{\mathrm{d}}^{\prime}$ & $\mathrm{Cl}_{1}^{\prime}$ & $\begin{array}{r}-\overline{\mathrm{C}_{\mathrm{p}, \mathrm{b}}} \\
\{\mathrm{BEC}\} \\
\end{array}$ & $\begin{array}{l}\mathrm{D} / \mathrm{H} \\
(\%)\end{array}$ \\
\hline $\begin{array}{c}\text { Sohankar } \\
(2006)[20]\end{array}$ & $\begin{array}{l}\text { LES \& experim } \\
\text { synthesis }\end{array}$ & $.5-5000$ & $0-2$ & & $\begin{array}{r}0.13 \\
\pm 0.01 \\
\end{array}$ & $\begin{array}{r}2.15 \\
\pm 0.15 \\
\end{array}$ & $\begin{array}{c}0.18 \\
\pm 0.05 \\
\end{array}$ & $\begin{array}{r}1.3 \\
\pm 0.3 \\
\end{array}$ & & $\sim 6$ \\
\hline $\begin{array}{l}\text { Present } \\
\text { reference } \\
\text { values }\end{array}$ & $\begin{array}{l}\text { synthesis from } \\
17 \text { experiments }\end{array}$ & 10-200 & $\begin{array}{c}0-2 \\
4.4-6.5 \\
10-14\end{array}$ & $\begin{array}{l}1.4 \pm 0.1 \\
1.4 \pm 0.1 \\
1.4 \pm 0.1\end{array}$ & $\begin{array}{l}.13 \pm 0.00 \\
.13 \pm 0.00 \\
.13 \pm 0.00\end{array}$ & $\begin{array}{l}2.15 \pm 0 . \\
1.9 \pm 0.1 \\
1.6 \pm 0.1\end{array}$ & $\begin{array}{l}.20 \pm 0.03 \\
.20 \pm 0.03 \\
.20 \pm 0.03\end{array}$ & $\begin{array}{c}1.2 \pm 0.2 \\
1.1 \pm 0.2 \\
0.65 \pm 0.25\end{array}$ & $\begin{array}{l}1.5\{1.4\} \pm 0.1 \\
1.3\{1.2\} \pm 0.1 \\
0.9\{0.8\} \pm 0.2\end{array}$ & $5-7.5$ \\
\hline
\end{tabular}

The blockage effect, $\mathrm{D} / \mathrm{H}$, modifies the mean velocity at obstacle level and the hydrodynamic forces exerted on it. However, when $\mathrm{D} / \mathrm{H}<10 \%$, its influence on the global quantities of Table 1 is weak comparing with I influence: the variations due to $\mathrm{D} / \mathrm{H}$ are generally smaller than $10 \%$ but can reach $15 \%$ on $\overline{\mathrm{C}_{\mathrm{p}, \mathrm{b}}}$, the quantity the most influenced by $\mathrm{D} / \mathrm{H}$. The blockage effect is a classical issue of closed wind tunnels, overcome by appropriate corrections of the results [22]. In the next to last column of Table 1, both the blockage effect corrected and uncorrected values of $\overline{\mathrm{C}_{\mathrm{p}, \mathrm{b}}}$ are men- 
tioned, with the corrected value into braces. The reference solutions resulting from our bibliographical review are given in the last row of Table 1, with their dispersion margin. As discussed above, they possibly depend on I and $\mathrm{D} / \mathrm{H}$. In the next to last line, they are compared with the reference solutions established by Sohankar [21]. These reference solutions agree well, with smaller dispersion margins for the present ones because LES results are not included in our analysis, contrary to [21].

Table 2 compiles experimental results on the averaged Nusselt numbers $\overline{\mathrm{Nu}}$ around a heated square cylinder at $\operatorname{Re} \geq 10^{4}$ [7-9], with experiments on mass transfer, using naphthalene sublimation in air flows around square cylinders [10]. Indeed, using Colburn relation and heat and mass transfer analogy, the average Sherwood number $\overline{\mathrm{Sh}}$ is shown to be related to $\overline{\mathrm{Nu}}$ by $\overline{\mathrm{Nu}} / \overline{\mathrm{Sh}}=(\mathrm{Pr} / \mathrm{Sc})^{1 / 3}$. That provides $\overline{\mathrm{Nu}}=0.6778 \overline{\mathrm{Sh}}$ at Prandtl number $\mathrm{Pr}=0.71$ and Schmidt number $\mathrm{Sc}=2.28$ for the diffusion of naphthalene vapor into air at ambient conditions [23].

The values of the front, side, rear and total average Nusselt numbers (noted $\overline{\mathrm{Nu}}_{\mathrm{f}}$, $\overline{\mathrm{Nu}}_{\mathrm{s}}, \overline{\mathrm{Nu}}_{\mathrm{r}}$ and $\overline{\mathrm{Nu}}_{\mathrm{t}}$ respectively) at $\mathrm{Re}=22,000$ are given in Table 2 . They are obtained either directly from the experimental correlations or from interpolations and integrations of the experimental profiles of the Nusselt or Sherwood numbers at other Reynolds numbers. Reference solutions with their dispersion margins for $\overline{\mathrm{Nu}}_{\mathrm{f}}, \overline{\mathrm{Nu}}_{\mathrm{s}}, \overline{\mathrm{Nu}}_{\mathrm{r}}$ and $\overline{\mathrm{Nu}}_{\mathrm{t}}$ at $\mathrm{Re}=22,000$ are then established from these interpolated results and given in the last line of Table 2 . They will be used below to validate the URANS simulations.

Table 2. Experimental correlations of $\overline{\mathrm{Nu}}$ around a heated square cylinder at $\mathrm{Re}>10^{4}$ and $\overline{\mathrm{Nu}} \mathrm{val}-$ ues at $\mathrm{Re}=22,000$. In the last line: reference solutions for $\overline{\mathrm{Nu}}$ at $\mathrm{Re}=22,000$. In all the experiments, flows are smooth: $\mathrm{I}<0.6 \%$. HT $=$ heat transfer; HMTA = heat and mass transfer analogy; correl. = correlation; I\&I = interpolation and integration of $\overline{\mathrm{Nu}}$ or $\overline{\mathrm{Sh}}$ profiles at $\mathrm{Re}=22,000$.

\begin{tabular}{|c|c|c|c|c|c|c|c|c|}
\hline Reference & $\begin{array}{c}\text { Metrology; } \\
\text { plotted profiles }\end{array}$ & $\begin{array}{l}\mathrm{D} / \mathrm{H} \\
(\%)\end{array}$ & $\begin{array}{l}\text { Method and } \\
\text { used figure nb in } \\
\text { the reference }\end{array}$ & $\begin{array}{l}\mathrm{Re} \\
\times 10^{-3}\end{array}$ & $\begin{array}{l}\overline{\mathrm{Nu}}_{\mathrm{f}} \\
\text { front }\end{array}$ & $\begin{array}{c}\overline{\mathrm{Nu}}_{\mathrm{s}} \\
\text { side or } \\
\text { top-bot. }\end{array}$ & $\begin{array}{l}\overline{\mathrm{Nu}}_{\mathrm{r}} \\
\text { rear }\end{array}$ & $\begin{array}{l}\overline{\mathrm{Nu}}_{\mathrm{t}} \\
\text { total }\end{array}$ \\
\hline $\begin{array}{l}\text { Igarashi } \\
\text { (1985) [7] }\end{array}$ & $\overline{\mathrm{HT}} \stackrel{\mathrm{TT}}{\mathrm{Nrofiles}}$ & $\begin{array}{l}3.8- \\
7.3\end{array}$ & $\begin{array}{c}\text { correlation } \\
\text { correl. value } \\
\text { I\&I of fig.4a }\end{array}$ & $\begin{array}{c}5.6-56 \\
22 \\
22 \\
\end{array}$ & 92.6 & 95.4-98.7 & 136.9 & $\begin{array}{c}0.14 \mathrm{Re}^{0.66} \\
102.8 \\
105.9\end{array}$ \\
\hline $\begin{array}{l}\text { Igarashi } \\
(1986) \text { [8] }\end{array}$ & $\overline{\mathrm{C}_{\mathrm{p}}}, \frac{\mathrm{HT}}{\mathrm{Nu}}$ profiles; & $\begin{array}{l}3.8- \\
7.3\end{array}$ & $\begin{array}{c}\text { correlation } \\
\text { correl. value }\end{array}$ & $\begin{array}{c}11-56 \\
22 \\
\end{array}$ & $\begin{array}{c}0.640 \mathrm{Re}^{1 / 2} \\
94.9\end{array}$ & $\begin{array}{c}0.131 \mathrm{Re}^{2 / 3} \\
102.9\end{array}$ & $\begin{array}{c}0.180 \mathrm{Re}^{2 / 3} \\
141.3\end{array}$ & $\begin{array}{c}0.14 \operatorname{Re}^{2 / 3} \\
109.9\end{array}$ \\
\hline $\begin{array}{l}\text { Tsutsui et al. } \\
\text { (2001) [9] }\end{array}$ & $\overline{\mathrm{C}_{\mathrm{p}}}, \frac{\mathrm{HT}}{\mathrm{Nu}}$ profiles & 5 & I\&I of fig.10 & 22 & 90.5 & 102.1-100.6 & 136.1 & 107.3 \\
\hline $\begin{array}{l}\text { Yoo et al. } \\
(2003) \text { [10] }\end{array}$ & $\begin{array}{c}\text { HMTA } \\
\text { Sh profiles }\end{array}$ & $10^{c}$ & $\begin{array}{l}\text { correl. from fig.5 } \\
\text { correl. value } \\
\text { I\&I of fig.3c }\end{array}$ & $\begin{array}{c}1.25-37 . \\
22 \\
22 \\
\end{array}$ & $\begin{array}{c}2.197 \mathrm{Re}^{0.386} \\
104.2 \\
109.3\end{array}$ & $\begin{array}{c}0.392 \mathrm{Re}^{0.55} \\
95.9 \\
106.5-100.4\end{array}$ & $\begin{array}{c}0.572 \mathrm{Re}^{0.545} \\
133.1 \\
139.5\end{array}$ & $\begin{array}{l}107.3 \\
113.9\end{array}$ \\
\hline$\overline{\overline{\mathrm{Nu}}}$ refere & ence values from $a$ & above & experiments & 22 & $100 \pm 10$ & $101 \pm 6$ & $137 \pm 5$ & $108 \pm 6$ \\
\hline
\end{tabular}

\section{URANS models, flow configuration and numerical methods}

The turbulent vortex shedding behind a square cylinder is a typical example of largescale coherent structures developing in a turbulent shear flow. The modelling of this flow type was addressed by Reynolds and Hussain [24, 25]. They proposed a double or a triple decomposition of all the quantities, $\mathrm{f}$, characterizing these flows, in order to 
separately describe their mean (time-averaged) contribution $\overline{\mathrm{f}}$, their periodic contribution $\tilde{\mathrm{f}}$ (the coherent fluctuations around the mean), their turbulent contribution $\mathrm{f}^{\prime}$, and the interactions between $\overline{\mathrm{f}}, \tilde{\mathrm{f}}$ and $\mathrm{f}$ '. Thus a time signal in this flow type can be decomposed as follows:

$$
\begin{gathered}
f(M, t)=\bar{f}(M)+\tilde{f}(M, t)+f^{\prime}(M, t) \\
f(M, t)=<f>(M, t)+f^{\prime}(M, t)
\end{gathered}
$$

where $\langle\mathrm{f}\rangle=\overline{\mathrm{f}}+\tilde{\mathrm{f}}$ is the phase average obtained by averaging over a large ensemble of observations of $f(M, t)$ at the same phase of the flow with respect to a reference oscillator. As explained in [25], the phase averaging process rejects the background turbulence and extracts only the organized motions from the total signal. In the case of the turbulent vortex shedding behind a square cylinder, it is observed that the coherent contributions $\langle\mathrm{f}>$ or $\tilde{\mathrm{f}}$ are quasi periodic and quasi two-dimensional in the plane $(\mathrm{O}, \mathrm{x}, \mathrm{y})$ transverse to the cylinder axis, and they are characterized by much larger space and time scales than those of the three-dimensional turbulence, f'. This explains the success of the URANS models for such flow configurations.

In the present study, the RNG and Realizable k- $\varepsilon$ models and the standard and low Reynolds number versions of the $\mathrm{k}-\omega$ SST model are tested in their basic forms (without changing the constants of the models) using the CFD software Ansys/Fluent. The Boussinesq hypothesis is used to relate the Reynolds stresses to the mean velocity gradients and the turbulent heat fluxes to the mean temperature gradients, with a turbulent Prandtl number $\mathrm{Pr}_{\mathrm{t}}=0.85$. We refer to $[2,3]$ and the Ansys/Fluent documentation [26] for the details.
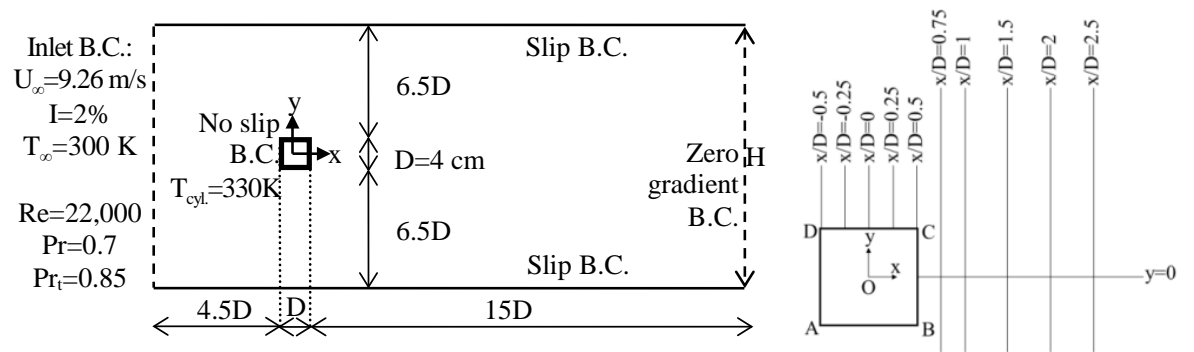

Fig. 2. Flow configuration and boundary conditions (left). Lines and dimensionless coordinates $\mathrm{x} / \mathrm{D}$ and $\mathrm{y} / \mathrm{D}$ of the lines used for profile plots around the square cylinder (right).

The 2D flow configuration of the present simulations is presented on Fig. 2. It is similar to the 2D plane $(\mathrm{O}, \mathrm{x}, \mathrm{y})$ in the 3D LES study performed by Boileau et al. (2013) [27]. An incompressible air flow, with the physical properties $\rho=1.1774 \mathrm{~kg} / \mathrm{m}^{3}$, $\mu=1.983 \times 10^{-5} \mathrm{~kg} / \mathrm{m} . \mathrm{s}, \mathrm{k}=2.851072 \times 10^{-2} \mathrm{~W} / \mathrm{m} . \mathrm{K}$ and $\mathrm{C}_{\mathrm{p}}=1006.43 \mathrm{~J} / \mathrm{kg} . \mathrm{K}$, is imposed at the inlet of a rectangular channel, with a uniform horizontal velocity $U_{\infty}=9.2632 \mathrm{~m} / \mathrm{s}$ and temperature $\mathrm{T}_{\infty}=300 \mathrm{~K}$, and with a turbulence intensity $\mathrm{I}=2 \%$. This air flow encounters a non-slipping square cylinder of diameter $\mathrm{D}=4 \mathrm{~cm}$, heated at $\mathrm{T}_{\mathrm{cyl}}=330 \mathrm{~K}$. Thus $\operatorname{Re}=\rho \mathrm{U}_{\infty} \mathrm{D} / \mu=22,000$ and $\operatorname{Pr}=\mu \mathrm{C}_{\mathrm{p}} / \mathrm{k}=0.7$. The channel is limited by two horizon- 
tal slipping boundaries located at 6.5D from the top and bottom faces of the cylinder. A zero-gradient boundary condition is applied at the channel outlet located at 15D downstream the cylinder rear face. The reference frame $(\mathrm{O}, \mathrm{x}, \mathrm{y})$ is at the square center with (Ox) and (Oy) the horizontal and vertical axes respectively.

The 2D incompressible URANS equations are solved with ANSYS/Fluent v17.2 [26] by a collocated finite volume method using a $2^{\text {nd }}$ order time implicit scheme and a $2^{\text {nd }}$ order Quick scheme in space. The SIMPLE algorithm is used for the velocity/pressure coupling and $\Delta \mathrm{t}=10^{-4} \mathrm{~s}$ for all the simulations. Since the period of the Von Karman vortices is $\tau=0.0332 \mathrm{~s}$ for a Strouhal number $\mathrm{St}=\mathrm{D} /\left(\tau \mathrm{U}_{\infty}\right)=0.13$, one period is equal to 332 time steps and $\Delta \mathrm{t}_{\mathrm{adim}}=\mathrm{U}_{\infty} \Delta \mathrm{t} / \mathrm{D}=0.023$; this was checked to provide time converged solutions. To get well converged statistics, the time integration duration is between 2 and $6 \mathrm{~s}$, which corresponds to $60 \tau$ to $200 \tau$.

To analyze the grid sensitivity of the solutions, five non uniform Cartesian grids refined close to the cylinder were used. The total mesh sizes $\mathrm{N}_{\mathrm{x}} \times \mathrm{N}_{\mathrm{y}}$ vary from $\mathrm{N}_{\mathrm{x}} \times \mathrm{N}_{\mathrm{y}}=188 \times 110$ for the coarsest grid (that has $20 \times 20$ uniform cells around the square cylinder with $5<\mathrm{y}^{+}<30$ to 50 ) to $\mathrm{N}_{\mathrm{x}} \times \mathrm{N}_{\mathrm{y}}=435 \times 310$ for the finest grid (that has $140 \times 140$ uniform cells around the square cylinder with $0<\mathrm{y}^{+}<5$ to 10 ). The different mesh sizes used are designated by the cell number around the square cylinder (e.g. $140 \times 140$ ). The total mesh size $N_{x} \times N_{y}$ is indicated in Table 3. For the finest grid $140 \times 140$, the first grid point close to the wall is located in the viscous sublayer because $\bar{y}^{+}<5$ (except on the front face where $\bar{y}^{+}<10$ ). For the coarsest grid $20 \times 20$, the first grid point is mainly located in the buffer layer because $5<\bar{y}^{+}<32$.

\section{$5 \quad$ Analysis of the global quantities and statistics}

The global quantities and statistics, characteristic of the flow and heat transfer around a square cylinder, are presented in Table 3 for the tested URANS models at $\mathrm{Re}=$ 22,000 and $\mathrm{I}=2 \%$. The results of the $\mathrm{k}-\varepsilon$ and $\mathrm{k}-\omega$ standard models are not presented because they are less good than with the improved versions and they are grid dependent. The reference solutions established in Tables 1 and 2 from the experimental results at $0<\mathrm{I} \leq 2 \%$ are reminded in the last line of Table 3 . The URANS values in italics in Table 3 are in the experimental reference ranges and the bold values in the yellow boxes are in a $10 \%$ accuracy from the references for $\mathrm{L}_{\mathrm{w}} / \mathrm{D}, \mathrm{St}, \overline{\mathrm{C}}_{\mathrm{d}}$ and the $\overline{\mathrm{Nu}}$ values, in a $20 \%$ accuracy for $C_{d}{ }^{\prime}$ and $\overline{C_{p, b}}$, and in the Sohankar [21] reference range for $C_{l}{ }^{\prime}$. Larger accuracy ranges are used for $\mathrm{C}_{\mathrm{d}}, \overline{\mathrm{C}_{\mathrm{p}, \mathrm{b}}}$ and $\mathrm{C}_{l}$ ' because they are harder to reproduce by URANS simulations. A first glance at Table 3 indicates that St and $\overline{\mathrm{C}}_{\mathrm{d}}$ are not pertinent criteria to qualify the URANS models: they are indeed not discriminant enough since nearly all the models are able to reproduce the St and $\overline{\mathrm{C}}_{\mathrm{d}}$ reference values. On the other hand, $\mathrm{L}_{\mathrm{w}} / \mathrm{D}, \mathrm{C}_{\mathrm{d}}, \overline{\mathrm{C}} \mathrm{p}, \mathrm{b}_{\mathrm{b}}$, the averaged Nusselt number on each face, $\overline{\mathrm{Nu}}_{\mathrm{f}}, \overline{\mathrm{Nu}}_{\mathrm{s}}$, $\overline{\mathrm{Nu}}_{\mathrm{r}}$, and, to a lesser extent, $\mathrm{C}_{l}$ and the averaged total Nusselt number $\overline{\mathrm{Nu}}_{\mathrm{t}}$, are quite hard to reproduce: very few values of these quantities are in italics in Table 3. 
Table 3. Flow and heat transfer global characteristics obtained from URANS simulations at $\mathrm{Re}=$ 22,000 and $\mathrm{I}=2 \%$. Comparison with the reference solutions of Tables 1 and 2 and [21] (two last lines). The values in italics fit the reference ranges and the bold values in the yellow boxes are in a $10 \%$ accuracy from the references ( $20 \%$ accuracy for $C_{d}^{\prime}$ and $\overline{C_{p, b}}$, or in [21] range for $\left.C_{l}^{\prime}\right)$.

\begin{tabular}{|c|c|c|c|c|c|c|c|c|c|c|c|}
\hline $\begin{array}{c}\text { URANS } \\
\text { Re= } \\
22,000\end{array}$ & $\begin{array}{c}\mathrm{N}_{\mathrm{x}} \times \mathrm{N}_{\mathrm{y}} \\
\text { (around } \\
\text { square cyl) }\end{array}$ & $\mathrm{L}_{w} / \mathrm{D}$ & St & $\overline{\mathrm{C}}_{\mathrm{d}}$ & $C_{d}^{\prime}$ & $\mathrm{Cl}_{1}^{\prime}$ & $\begin{array}{c}-\overline{\mathrm{C}_{\mathrm{p}, \mathrm{b}}} \\
\{\mathrm{BEC}\}\end{array}$ & $\begin{array}{l}\overline{\mathrm{Nu}}_{\mathrm{f}} \\
\text { front }\end{array}$ & $\begin{array}{c}\overline{\mathrm{Nu}}_{\mathrm{s}} \\
\text { side or } \\
\text { top-bot. }\end{array}$ & $\begin{array}{l}\overline{\mathrm{Nu}}_{\mathrm{r}} \\
\text { rear }\end{array}$ & $\begin{array}{l}\overline{\mathrm{Nu}}_{\mathrm{t}} \\
\text { total }\end{array}$ \\
\hline \multirow{4}{*}{$\begin{array}{l}\mathrm{k}-\omega \\
\text { SST }\end{array}$} & $\begin{array}{c}188 \times 110 \\
(20 \times 20)\end{array}$ & 1.12 & 0.138 & $\begin{array}{c}2.240 \\
\pm 0.005\end{array}$ & $\begin{array}{c}0.207 \\
\pm 0.001\end{array}$ & $\begin{array}{c}1.42 \\
\pm 0.02\end{array}$ & 1.163 & 70.8 & $\begin{array}{l}72.4 \\
72.2\end{array}$ & 105.0 & $\begin{array}{l}80.1 \\
\pm 3.0\end{array}$ \\
\hline & $\begin{array}{c}290 \times 190 \\
(60 \times 60)\end{array}$ & 1.13 & 0.132 & $\begin{array}{c}2.215 \\
\pm 0.005\end{array}$ & $\begin{array}{c}0.239 \\
\pm 0.005\end{array}$ & $\begin{array}{c}1.47 \\
\pm 0.01\end{array}$ & 1.192 & 120.1 & $\begin{array}{l}95.3 \\
95.5\end{array}$ & 120.8 & $\begin{array}{c}108.0 \\
\pm 3.8\end{array}$ \\
\hline & $\begin{array}{c}365 \times 250 \\
(100 \times 100)\end{array}$ & 1.26 & 0.132 & $\begin{array}{c}2.220 \\
\pm 0.005\end{array}$ & $\begin{array}{l}0.280 \\
\pm 0.01\end{array}$ & $\begin{array}{c}1.54 \\
\pm 0.02\end{array}$ & 1.189 & 136.5 & $\begin{array}{l}98.5 \\
98.2 \\
\end{array}$ & 143.5 & $\begin{array}{c}119.2 \\
\pm 6\end{array}$ \\
\hline & $\begin{array}{c}435 \times 310 \\
(140 \times 140)\end{array}$ & 1.325 & 0.122 & $\begin{array}{c}2.220 \\
\pm 0.005\end{array}$ & $\begin{array}{l}0.325 \\
\pm 0.01\end{array}$ & $\begin{array}{c}1.57 \\
\pm 0.02 \\
\end{array}$ & 1.197 & 135.9 & $\begin{array}{l}96.7 \\
97.0 \\
\end{array}$ & 148.0 & $\begin{array}{c}119.4 \\
\pm 7.6\end{array}$ \\
\hline \multirow{4}{*}{$\begin{array}{c}\mathrm{k}-\omega \\
\mathrm{SST} \\
\text { low Re }\end{array}$} & $\begin{array}{l}188 \times 110 \\
(20 \times 20)\end{array}$ & 1.24 & 0.138 & $\begin{array}{c}2.225 \\
\pm 0.005 \\
\end{array}$ & $\begin{array}{c}0.234 \\
\pm 0.001 \\
\end{array}$ & $\begin{array}{c}1.337 \\
\pm 0.005 \\
\end{array}$ & 1.143 & 70.9 & $\begin{array}{l}69.7 \\
69.5 \\
\end{array}$ & 105.2 & $\begin{array}{r}78.9 \\
\pm 3.9 \\
\end{array}$ \\
\hline & $\begin{array}{c}290 \times 190 \\
(60 \times 60)\end{array}$ & 1.39 & 0.139 & $\begin{array}{c}2.220 \\
\pm 0.001\end{array}$ & $\begin{array}{c}0.287 \\
\pm 0.001\end{array}$ & $\begin{array}{l}1.405 \\
\pm 0.01\end{array}$ & 1.159 & 119.1 & $\begin{array}{l}84.3 \\
84.5\end{array}$ & 118.6 & $\begin{array}{r}101.7 \\
\pm 4.9\end{array}$ \\
\hline & $\begin{array}{c}365 \times 250 \\
(100 \times 100)\end{array}$ & 1.52 & 0.129 & $\begin{array}{c}2.25 \\
\pm 0.01\end{array}$ & $\begin{array}{c}0.37 \\
\pm 0.02\end{array}$ & $\begin{array}{c}1.45 \\
\pm 0.02\end{array}$ & 1.170 & 132.6 & $\begin{array}{l}85.9 \\
85.9\end{array}$ & 138.4 & $\begin{array}{c}110.7 \\
\pm 7.3\end{array}$ \\
\hline & $\begin{array}{c}435 \times 310 \\
(140 \times 140)\end{array}$ & 1.54 & 0.142 & $\begin{array}{c}2.39 \\
\pm 0.01\end{array}$ & $\begin{array}{c}0.59 \\
\pm 0.01\end{array}$ & $\begin{array}{c}1.69 \\
\pm 0.01\end{array}$ & 1.222 & 130.3 & $\begin{array}{l}88.9 \\
89.0\end{array}$ & 151.5 & $\begin{array}{c}114.9 \\
\pm 7.3\end{array}$ \\
\hline \multirow{4}{*}{$\begin{array}{c}\mathrm{k}-\varepsilon \\
\mathrm{RNG}\end{array}$} & $\begin{array}{l}188 \times 110 \\
(20 \times 20) \\
\end{array}$ & 2.15 & 0.134 & 1.908 & 0.0081 & $\begin{array}{l}0.567 \\
\pm .001 \\
\end{array}$ & 0.839 & 119.8 & $\begin{array}{l}87.8 \\
87.9 \\
\end{array}$ & 85.5 & $\begin{array}{l}95.2 \\
\pm 0.2 \\
\end{array}$ \\
\hline & $\begin{array}{c}290 \times 190 \\
(60 \times 60)\end{array}$ & 1.64 & 0.132 & 2.041 & 0.0277 & $\begin{array}{l}0.959 \\
\pm .001 \\
\end{array}$ & 0.972 & 125.9 & $\begin{array}{l}88.0 \\
88.0 \\
\end{array}$ & 91.1 & $\begin{array}{l}98.2 \\
\pm 0.3 \\
\end{array}$ \\
\hline & $\begin{array}{c}365 \times 250 \\
(100 \times 100)\end{array}$ & 1.58 & 0.128 & $\begin{array}{c}2.050 \\
\pm 0.001 \\
\end{array}$ & $\begin{array}{c}0.0328 \\
\pm 0.0001\end{array}$ & $\begin{array}{l}1.048 \\
\pm .002 \\
\end{array}$ & 0.993 & 141.6 & $\begin{array}{l}90.7 \\
90.6\end{array}$ & 95.1 & $\begin{array}{c}104.5 \\
\pm 0.8 \\
\end{array}$ \\
\hline & $\begin{array}{c}435 \times 310 \\
(140 \times 140)\end{array}$ & 1.69 & 0.063 & $\begin{array}{c}2.040 \\
\pm 0.001\end{array}$ & $\begin{array}{c}0.0291 \\
\pm 0.0001\end{array}$ & $\begin{array}{l}0.956 \\
\pm .001\end{array}$ & 0.983 & 143.3 & $\begin{array}{l}91.2 \\
91.2 \\
\end{array}$ & 93.6 & $\begin{array}{c}104.8 \\
\pm 0.8\end{array}$ \\
\hline \multirow{4}{*}{$\begin{array}{c}\mathrm{k}-\varepsilon \\
\text { realiz- } \\
\text { able }\end{array}$} & $\begin{array}{c}188 \times 110 \\
(20 \times 20) \\
\end{array}$ & 1.98 & 0.147 & $\begin{array}{c}1.949 \\
\pm 0.0001 \\
\end{array}$ & $\begin{array}{c}0.0180 \\
\pm 0.0001 \\
\end{array}$ & $\begin{array}{c} \pm 0.634 \\
\pm 0.0001 \\
\end{array}$ & 0.926 & 83.8 & $\begin{array}{l}71.2 \\
71.2 \\
\end{array}$ & 85.3 & $\begin{array}{r}77.9 \\
\pm 0.25 \\
\end{array}$ \\
\hline & $\begin{array}{c}290 \times 190 \\
(60 \times 60) \\
\end{array}$ & 1.38 & 0.135 & $\begin{array}{c}2.190 \\
\pm 0.0001 \\
\end{array}$ & $\begin{array}{c}0.0377 \\
\pm 0.0001 \\
\end{array}$ & $\begin{array}{l} \pm 1.333 \\
\pm 0.001 \\
\end{array}$ & 1.146 & 121.6 & $\begin{array}{l}75.2 \\
75.3 \\
\end{array}$ & 89.9 & $\begin{array}{c}90.5 \\
\pm 0.09 \\
\end{array}$ \\
\hline & $\begin{array}{c}365 \times 250 \\
(100 \times 100) \\
\end{array}$ & 1.38 & 0.135 & $\begin{array}{r}2.190 \\
\pm 0.0001 \\
\end{array}$ & $\begin{array}{c}0.0377 \\
\pm 0.0001 \\
\end{array}$ & $\begin{array}{l} \pm 1.333 \\
\pm 0.001 \\
\end{array}$ & 1.146 & 134.3 & $\begin{array}{l}77.4 \\
77.5 \\
\end{array}$ & 90.1 & $\begin{array}{l}94.8 \\
\pm 0.8 \\
\end{array}$ \\
\hline & $\begin{array}{c}435 \times 310 \\
(140 \times 140) \\
\end{array}$ & 1.33 & 0.126 & $\begin{array}{c}2.210 \\
\pm 0.0001\end{array}$ & $\begin{array}{c}0.0560 \\
\pm 0.0001\end{array}$ & $\begin{array}{l} \pm 1.538 \\
\pm 0.001\end{array}$ & 1.182 & 133.1 & $\begin{array}{l}79.4 \\
79.4 \\
\end{array}$ & 84.1 & $\begin{array}{r}94.0 \\
\pm 0.8 \\
\end{array}$ \\
\hline \multicolumn{2}{|c|}{$\begin{array}{c}\text { Sohankar [21] } \\
5.10^{3}<\mathrm{Re}<5.10^{6} \\
\end{array}$} & & $\begin{array}{r}0.13 \\
\pm 0.01 \\
\end{array}$ & $\begin{array}{c}2.15 \\
\pm 0.15\end{array}$ & $\begin{array}{c}0.18 \\
\pm 0.05\end{array}$ & $\begin{array}{c}1.3 \\
\pm 0.3 \\
\end{array}$ & & & & & \\
\hline \multicolumn{2}{|c|}{$\begin{array}{c}\text { Present refer. values } \\
10^{4}<\operatorname{Re}<2.10^{5} ; 0<\mathrm{I}<2 \%\end{array}$} & $\begin{array}{c}1.4 \\
\pm 0.1\end{array}$ & $\begin{array}{c}0.13 \\
\pm 0.008\end{array}$ & $\begin{array}{l}2.15 \\
\pm 0.1\end{array}$ & $\begin{array}{c}0.20 \\
\pm 0.03\end{array}$ & $\begin{array}{c}1.2 \\
\pm 0.2\end{array}$ & $\begin{array}{l}\{1.4\} \\
\pm 0.1\end{array}$ & $\begin{array}{l}100 \\
\pm 10\end{array}$ & $\begin{array}{c}101 \\
\pm 6\end{array}$ & $\begin{array}{c}137 \\
\pm 5\end{array}$ & $\begin{array}{l}108 \\
\pm 6\end{array}$ \\
\hline
\end{tabular}

It appears that the k- $\varepsilon$ RNG model does not well reproduce the experimental results, except $\mathrm{St}, \overline{\mathrm{C}}_{\mathrm{d}}$, and $\overline{\mathrm{Nu}}_{\mathrm{t}}$. The result quality also depends on the grid size: only the mesh $(100 \times 100)$ provides good enough results. The $k-\varepsilon$ realizable model presents better results than the RNG version for the flow dynamics (except $C_{d}$ ). However, it provides poor values of the Nusselt numbers. The best tested URANS model is k- $\omega$ SST because it allows recovering most of the experimental results whatever the grid size used. The exceptions are for the averaged Nusselt numbers that can be hard to obtain 
with the coarser grids $(20 \times 20$ cells around the cylinder) and, on the front face, where $\overline{\mathrm{Nu}}_{\mathrm{f}}$ is over-estimated and strongly grid dependent. Finally, a low Re version of the k$\omega$ SST model has been tested, in which the turbulent viscosity is damped by a damping function in the low Re regions. It does not improve the basic k- $\omega$ SST model.

\section{Analysis of thermal and dynamical profiles around the cylinder}

Since the k- $\omega$ SST model is clearly the best among the tested models to mimic the global dynamical and thermal behaviors of the flow, we investigate now its ability to reproduce the local behaviors around the square cylinder. The lines used to plot the field and wall profiles around the square cylinder are drawn on Fig. 2 (right). Comparisons of these profiles with experimental and LES results are analyzed below. The main used LES results are extracted from Boileau et al. (2013) [27] in which a high performance 3D simulation with heat transfer was carried out on an unstructured mesh of 12.6 million cells, with $\mathrm{y}^{+}<2$ on most of the square cylinder surface.

On Fig. 3, longitudinal profiles of the time-averaged streamwise velocity component, $\overline{\mathrm{u}}$, and time-averaged total kinetic energy, $\overline{\mathrm{k}}_{\text {tot }}$, along the symmetry axis $\mathrm{y}=0$ in the cylinder wake (see Fig. 2 right) are presented. The profiles from the k- $\omega$ SST simulations are compared with experimental and LES results. On Fig. 3 (left), the k- $\omega$ SST profiles of $\overline{\mathrm{u}} / \mathrm{U}_{\infty}$ along $\mathrm{y}=0$ agree very well with the experimental profiles $[5,17,19]$ in the near wake, for $x / D<2.5$. In this zone, the $k-\omega$ SST profiles converge towards the experimental results with the grid refinement. The agreement of the LES profile [27] is a bit less good in this zone since the recirculation length predicted by LES is approximately equal to $L_{w} / D \approx 1$ while the experiments give $L_{w} / D \approx 1.4$. On the other hand, in the far wake, for $\mathrm{x} / \mathrm{D}>3$, LES is able to predict the very slow velocity recovery observed experimentally in $[5,20]$. This slow velocity recovery is due to the presence of the large turbulent eddies of the Von-Karman alley. A faster velocity recovery is observed in Durao et al. experiments [18] because both the background turbulence intensity $(\mathrm{I}=6 \%)$ and the blockage effect $(\mathrm{D} / \mathrm{H}=12.8)$ are much larger than in $[5,20]$ where $\mathrm{I}<3 \%$ and $\mathrm{D} / \mathrm{H} \leq 7$ : indeed the turbulent dissipation and the flow confinement both promote the large eddy disintegration and the velocity recovery. The URANS simulations also present this behavior on the largest grids because the turbulent dissipation is promoted in this case. But if the grid is refined (see the k- $\omega$ SST case $140 \times 140$ ), the URANS profiles better agree with the experiments.

The fluctuations in the wake are depicted on Fig. 3 (right) through the profiles of the time averaged total kinetic energy, $\overline{\mathrm{k}}_{\mathrm{tot}}$. In the URANS simulations, it is defined as the sum of the turbulent and coherent (or quasi-periodic) kinetic energies:

$$
\overline{\mathrm{k}}_{\mathrm{tot}}(\mathrm{M})=\overline{<\mathrm{k}>}(\mathrm{M})+\overline{\mathrm{k}}(\mathrm{M})
$$

with the time-averaged coherent kinetic energy defined as:

$$
\overline{<\mathrm{k}>}(\mathrm{M})=\frac{1}{2}\left(\overline{\mathrm{RMS}^{2}(<\mathrm{u}>(\mathrm{M}, \mathrm{t}))}+\overline{\mathrm{RMS}^{2}(<\mathrm{v}>(\mathrm{M}, \mathrm{t}))}\right)
$$



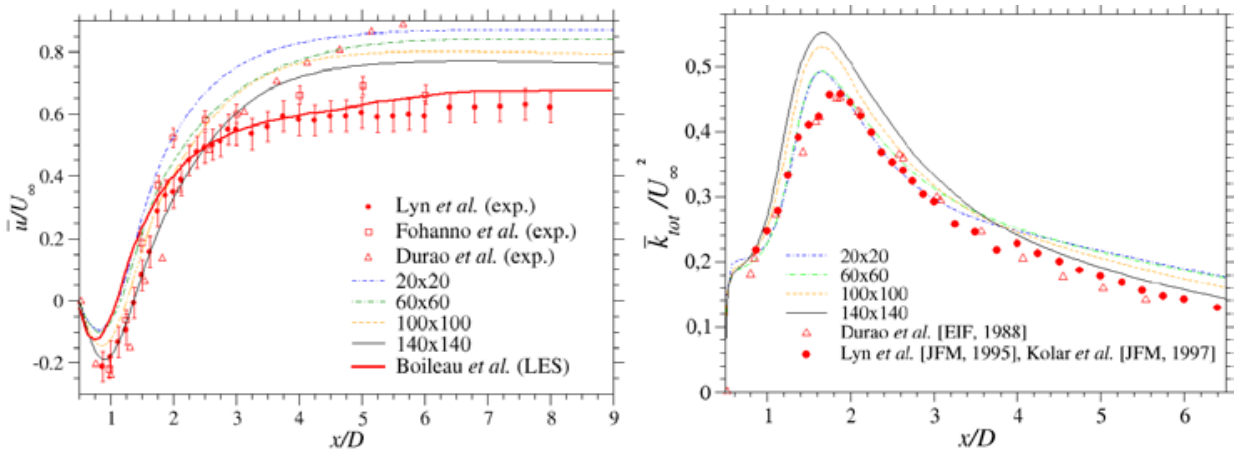

Fig. 3. Longitudinal profiles of the time-averaged streamwise velocity component and timeaveraged total kinetic energy in the cylinder wake along $y=0$ (Fig. 2 right). Comparison of the k- $\omega$ SST results with experimental [5, 6, 18, 20] and LES [27] results.

and $\bar{k}(M)$ the time-averaged turbulent kinetic energy. In the experiments, $\bar{k}_{\text {tot }}(M)$ is directly computed from the measured time signals of the velocity components as:

$$
\overline{\mathrm{k}}_{\mathrm{tot}}(\mathrm{M})=\frac{1}{2}\left(\overline{\mathrm{RMS}^{2}(\mathrm{u}(\mathrm{M}, \mathrm{t}))}+\overline{\mathrm{RMS}^{2}(\mathrm{v}(\mathrm{M}, \mathrm{t}))}\right)
$$

In Fig. 3 (right), the $k-\omega$ SST profiles of $\bar{k}_{\text {tot }}$ are compared with the experimental results from $[5,6,18]$. It appears that the $\mathrm{k}-\omega \mathrm{SST}$ profiles overestimate $\overline{\mathrm{k}}_{\mathrm{tot}}$ compared to the experiments, particularly around $x / D=2$. This could then explain the faster velocity recovery already observed in Fig. 3 (left), the total fluctuations (turbulent and coherent) promoting the break-up of the large eddies.

The transverse/vertical profiles of the time-averaged and fluctuating/RMS streamwise velocity component, obtained from the $k-\omega$ SST simulations on four different grids, are plotted on Figs. 4 and 5. On Fig. 4, the profiles are located in the top near wake of the cylinder, for $0.75 \leq x / D \leq 2.5$ and $0 \leq y / D \leq 2.5$. On Fig. 5 , they are located above the top surface of the cylinder along the vertical lines $\mathrm{x} / \mathrm{D}=-0.5$ to 0.5 drawn on Fig. 2 (right). They are compared with experiments [4, 5] and LES [27, 28]. Globally, all these profiles are in good agreement with the experiments. Furthermore, the k- $\omega$ SST solutions are as accurate as the LES solutions when comparing with the experiments. The URANS averaged streamwise velocity profiles, $\overline{\mathrm{u}}(\mathrm{y})$, perfectly agree with the experimental and LES results, particularly with the finest grid $140 \times 140$, both above the cylinder (Fig. 5) and in its wake (Fig. 4). A good enough agreement is also observed for the averaged transverse velocity profiles $\bar{v}(y)$ (not shown) except in the near wake for $\mathrm{x} / \mathrm{D} \leq 1$ where the main discrepancies are observed. As for the velocity fluctuation profiles, u'(y) (and v'(y); not shown), the k- $\omega$ SST simulations seem to slightly overestimate the experimental values, at least for $\mathrm{y} / \mathrm{D}>0.7$. 

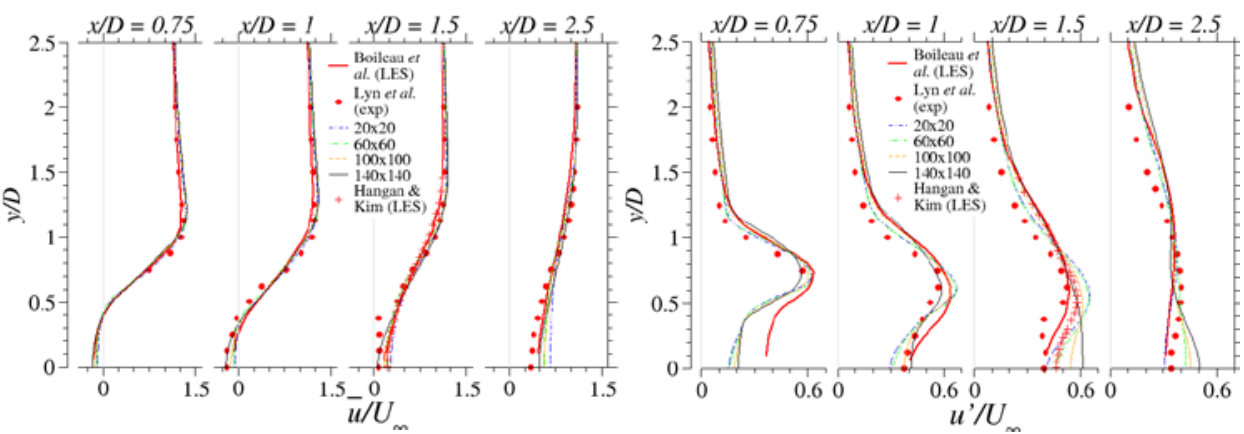

Fig. 4. Transverse profiles of the time-averaged (left) and fluctuating/RMS (right) streamwise velocity component in the cylinder top wake. Comparison with experiments [5] and LES [27, 28].
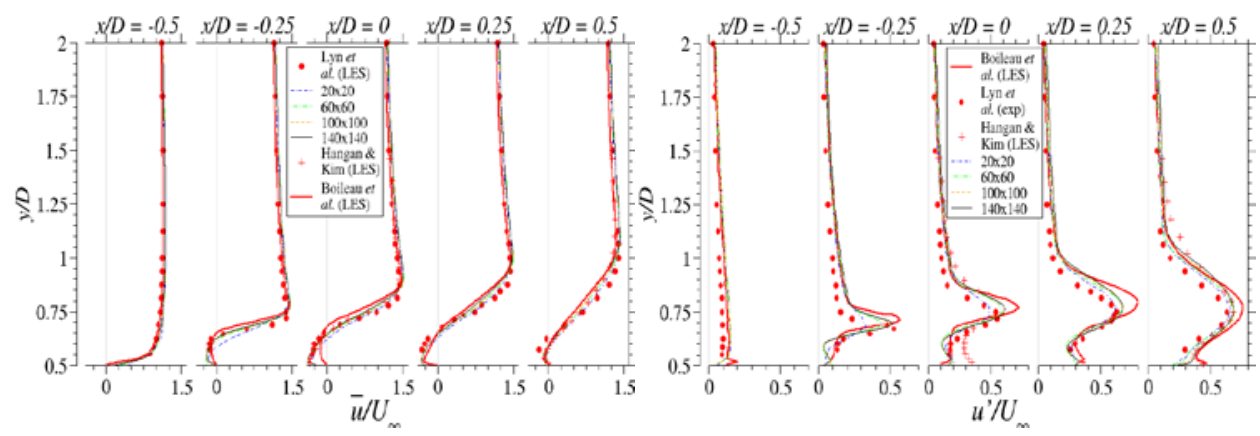

Fig. 5. Same as Fig. 5 but above the cylinder top face and comparison with experiments [4].

On Fig. 5, it is very satisfying to observe that the k- $\omega$ SST model is able to capture the complex flow physics above the cylinder. The flow separation at the leading edge of the bluff body, the thickness of the shear layer, the backflow with a negative velocity in the recirculation below the separated shear layer are well reproduced by this URANS model (see $\overline{\mathrm{u}}(\mathrm{y})$ on the left of Fig. 5). Moreover the intensity of the velocity fluctuations in the flapping shear layer are well captured, sometimes better than with the LES (see u'(y) on the right of Fig. 5).

We consider now on Fig. 6 the wall profiles of the time-averaged pressure coefficient, $\overline{\mathrm{C}_{\mathrm{p}}}$, and Nusselt number, $\overline{\mathrm{Nu}}$, around the cylinder surface. On Fig. 6 (left), the $\overline{\mathrm{C}_{\mathrm{p}}}$ profiles on the front and rear faces and on the trailing edges of the horizontal faces (closed to points B and $\mathrm{C}$ ) are in a fairly good agreement with the experimental data $[15,17]$ and the recent DNS [13]. However discrepancies are observed on the top and bottom plates close to the leading edge (close to points $A$ and $D$ ): the $\overline{C_{p}}$ values are underestimated by the k- $\omega$ SST model in this zone. These inaccuracies are maybe due to a too poor spatial resolution in these critical zones, where high speeds and boundary layer separations are observed (the $\mathrm{y}^{+}$values, not shown here, are maximum at points A and D). For the LES [27], an opposite agreement is observed: the maximum discrepancies with the experimental data are on the trailing edges of the horizontal faces and on the rear face. 

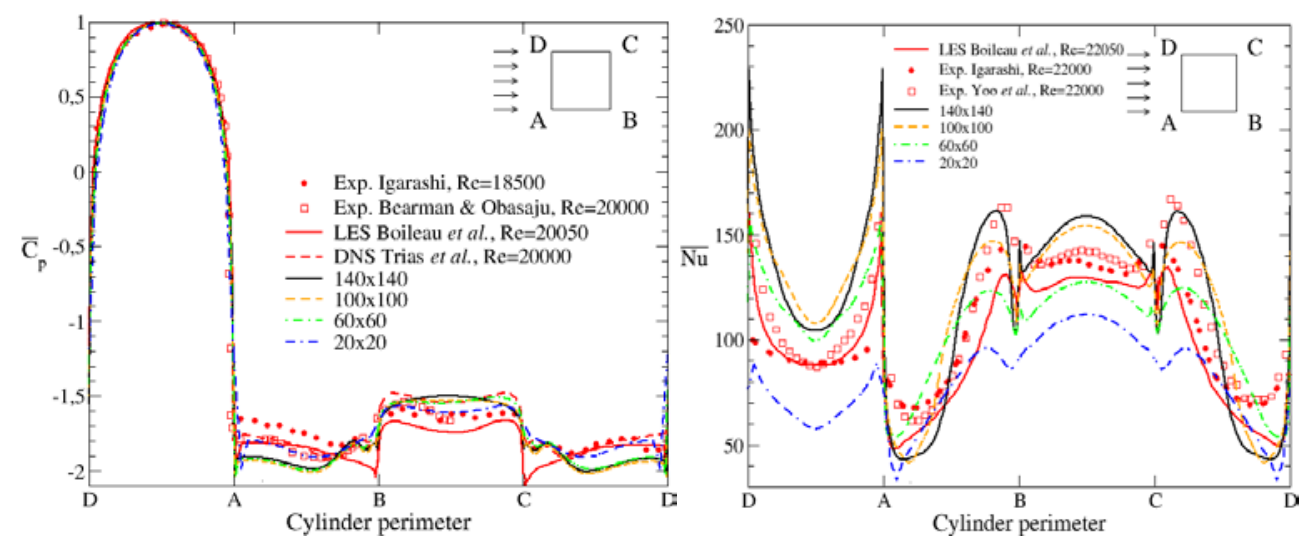

Fig. 6. Profiles of the time-averaged pressure coefficient (left) and Nusselt number (right) around the cylinder surface. Comparisons with experiments [14, 16] \& [7, 10], LES [27] and DNS [13]

The time-averaged Nusselt number is plotted on Fig. 6 (right). The k- $\omega$ SST profiles are compared to the LES [27] and experimental solutions [7, 8, 10]. As the Nusselt profiles of these experiments are not measured at $\mathrm{Re}=22,000$, the $\overline{\mathrm{Nu}}$ experimental profiles of Fig. 6 (right) are interpolated from the $\overline{\mathrm{Nu}}$ profiles plotted in [7, 8, $10]$ at other Re values. We have used the $\overline{\mathrm{Nu}}$ profiles at the closest Re values from 22,000 and the interpolation laws as a function of Re established in these references, whose equations are reported in Table 2 for each cylinder face. Table 2 has shown that the maximum averaged heat transfer around a square cylinder is located on the rear face. Fig. 6 (right) more precisely indicates that the maximum Nusselt numbers are located on the front face close to the angles (due to higher velocities at points A and $\mathrm{D}$ ) and at the trailing edges of the horizontal faces (due to the flapping shear layers [4]) and on the rear face (due to the high velocity fluctuation level in the near wake of the cylinder; see Figs. 4 (right) and 5 (right)). When the grids are refined from $20 \times 20$ to $140 \times 140$ cells around the cylinder, the k- $\omega$ SST $\overline{\mathrm{Nu}}$ solutions seem to converge, at least on the front and rear faces (a variation is still present on the horizontal faces below the separated shear layer). Once again, the discrepancy between the URANS solution on the finest grid and the two experimental solutions $[7,10]$ is equivalent to the discrepancy between LES [27] and experiments, except on the front face where the k- $\omega$ SST solutions overestimate by $20 \%$ the experimental values.

\section{Conclusions}

The turbulent forced convection at high Reynolds number $\left(\operatorname{Re}>10^{4}\right)$ around a square cylinder is a very interesting test case to qualify turbulence models because it contains very rich flow features: laminar/turbulent transition, flow separation, backward recirculation, turbulent wake flow with vortex shedding and heat transfer around the obstacle. In the first part of the paper, reference quantities describing the main flow and heat transfer characteristics of this test case have been set-up from a synthesis of 
around twenty distinct experiments. The flow characteristics concern the wake length, the Strouhal number and the time-averaged and RMS of the drag, lift and pressure coefficients. Furthermore a reference solution for the time-averaged wall Nusselt number on each cylinder face is built for the first time.

From the results of the various $k-\varepsilon$ and $k-\omega$ models tested, it has been shown that the Strouhal number, the averaged drag coefficient and the RMS of the lift coefficient, which are usually used criteria to qualify numerical models, are in fact not selective enough to distinct between the appropriate and the non-pertinent models. On the other hand, quantities like the wake length, the RMS of the drag coefficient and the averaged Nusselt number on each face are hardly predictable.

Among the URANS models tested, it has been shown that the k- $\omega$ SST model is the most relevant to predict the flow dynamics and heat transfer in the present flow configuration, whatever the grid sizes for wall Reynolds numbers such as $\mathrm{y}^{+}<20$. The $k-\varepsilon$ type models provide unsatisfactory results for the present test case, particularly for heat transfer. The low Re version of the k- $\omega$ SST model does not improve it.

An analysis of the averaged and fluctuating velocity profiles around the square cylinder and the wall profiles of the averaged pressure coefficients and Nusselt number has been carried out, with numerous comparisons with LES and experimental results. Compared with the experiments, the k- $\omega$ SST results are shown to be as accurate as the LES results [27], but for a much smaller computational cost, compatible with industrial applications. We have indeed evaluated the ratio of the LES CPU time in [27] to the present URANS CPU time: it varies between one and two magnitude orders according to the grid sizes.

To conclude, this paper proves that the k- $\omega$ SST model can be an excellent model for simple industrial flow configurations such as the present one, in particular when a sort of scale separation is present between the space and time scales of the largest eddies (here the von-Karman vortices) and those of the turbulence. However one cannot conclude that the k- $\omega$ SST model will be pertinent in more complex flow geometries, in particular when several characteristic frequencies of the flow will interact, like in the interaction between a wake flow and a free jet flow for instance.

\section{Acknowledgments}

Asmaa Ait Daraou and Salmane Merzouki are gratefully acknowledged for their contribution to the present work.

\section{References}

1. Sommerer Y., Couton D., Plourde F.: Dissipative Equipement thermal integration in powerplant compartment: experimental and numerical evaluation of heat transfer coefficient, Proc. of the ASME Turbo Expo Conference, Düsseldorf, Germany, GT2014-25255 (2014).

2. Wilcox D. C.: Turbulence modelling for CFD, DCW Indust., Inc., La Canada, California (1993).

3. Vieser W., Esch T., Menter F.: Heat transfer predictions using advanced two-equation turbulence models, CFX Validation Report, CFX-VAL10/0602, (2002) 1-65. 
4. Lyn D. A., Rodi W.: The flapping shear layer formed by flow separation from the forward corner of a square cylinder, J. Fluid Mech., 267 (1994) 353-376.

5. Lyn D. A., Einav S., Rodi W., Park J.-H.: A laser-Doppler velocimetry study of ensemble-averaged characteristics of the turbulent near wake of a square cylinder, J. Fluid Mech., 304 (1995) 285-399.

6. Kolar V., Lyn D. A., Rodi W.: Ensemble-averaged measurements in the turbulent near wake of two side-by-side square cylinders, J. Fluid Mech. 346 (1997) 201-237.

7. Igarashi T.: Heat transfer from a square prism to air stream, Int. J. Heat Mass Trans., 28 (1985) 175-181.

8. Igarashi T.: Local heat transfer from a square prism to an airstream, Int. J. Heat Mass Trans., 29 (1986) 777-784.

9. Tsutsui T., Igarashi T., Nakamura H.: Drag reduction and heat transfer enhancement of a square prism, JSME Int. J., Series B, 44 (2001) 575-583.

10. Yoo S.-Y., Park J.-H., Chung C.-H., Chung M.-K.: An experimental study on heat/mass transfer from a rectangular cylinder, J. Heat Transfer 125 (2003) 1163-1169.

11. Minguez M., Brun C., Pasquetti R., Serre E.: Experimental and high-order LES analysis of the flow in near-wall region of a square cylinder, Int. J. Heat Fluid Flow, 32 (2011) 558-566.

12. Brun C., Aubrun S., Goossens T., Ravier Ph.: Coherent structures and their frequency signature in separated shear layer on the sides of a square cylinder, Flow Turbul. Combust., 81 (2008) 97-114.

13. Trias F.X., Gorobets A., Oliva A. Turbulent flow around a square cylinder at Reynolds number 22,000: a DNS study, Computers and Fluids, 123 (2015) 87-98.

14. Lee B. E.: The effect of turbulence on the surface pressure field of a square prism, J. Fluid Mech., 69 (1975) 263-282

15. Bearman P. W., Obasaju E. D.: An experimental study of pressure fluctuations on fixed and oscillating square section cylinders, J. Fluid Mech., 119 (1982) 297-321.

16. Nakamura Y., Ohya Y.: The effects of turbulence on the mean flow past two-dimensional rectangular cylinders, J. Fluid Mech. 149 (1984) 255-273.

17. Igarashi T.: Characteristics of the flow around rectangular cylinders (The case of the angle of attack 0 deg), Bulletin of JSME, 28 (1985) 1690-1696.

18. Durão D. F. G., Heitor M. V., Pereira J. C. F.: Measurements of turbulent and periodic flows around a square cross section cylinder, Exp. Fluids, 6 (1988) 298-304.

19. Tamura T., Miyagi T.: The effect of turbulence on aerodynamic forces on a square cylinder with various corner shapes, J. Wind Eng. Ind. Aerodyn., 83 (1999) 135-145.

20. Fohanno S., Martinuzzi R. J.: A phase-averaged analysis of droplet dispersion in the wake of a square cylinder in a uniform stream, J. Fluids Engineering, 126 (2004) 110-119.

21. Sohankar A.: Flow over a bluff body from moderate to high Reynolds numbers using large eddy simulation, Computers \& Fluids, 35 (2006) 1154-1168.

22. Maskell E. C.: A theory of the blockage effects on bluff bodies and stalled wings in a closed wind tunnel, Reports and Memoranda n³400, Aeronautical Research Council (1963).

23. Chen P.-H., Miao J.-M., Jian C.-S.: Novel technique for investigating the temperature effect on the diffusion coefficient of naphthalene into air, Rev. Sci. Instrum., 67 (1996) 2831-2836.

24. Reynolds W. C., Hussain A. K. M. F.: The mechanics of an organized wave in turbulent shear flow. Part 3. Theoretical models and comparisons with experiments, J. Fluid Mech., 54 (1972) 263-288.

25. Hussain A. K. M. F.: Coherent structures - reality and myth, Phys. Fluids, 26 (1983) 2816-2850.

26. ANSYS Fluent Theory Guide, Release 17.2. Ansys Inc. Canonsburg (2016).

27. Boileau M., Duchaine F., Jouhaud J.-C., Sommerer Y.: Large-eddy simulation of heat transfer around a square cylinder using unstructured grids. AIAA J. 51(2) (2013) 372-385.

28. Hangan H., Kim J., Aerodynamic slot-control for 2D square prisms. J. Wind Eng. Ind. Aerodyn., 91 (2003) 1847-1857. 